\title{
An Overview of the Role of Non-State Actors in Preventing and Combatting Corruption in Botswana: Challenges and Opportunities
}

\author{
Abiodun Marumo Tito Omotoye ${ }^{1}$ \\ ${ }^{1}$ Botswana Institute for Development Policy Analysis, Botswana \\ Correspondence: Abiodun Marumo Tito Omotoye, Botswana Institute for Development Policy Analysis, \\ Botswana. E-mail: omotoyem@bidpa.bw
}

Received: May 11, 2016 Accepted: June 2, 2016 Online Published: September 4, 2016

doi:10.5539/par.v5n2p6 URL: http://dx.doi.org/10.5539/par.v5n2p6

\begin{abstract}
Botswana has been lauded, regionally and internationally, for its commitment towards building a capable, democratic and developmental state. However, the country's national anti-corruption agency, the Directorate on Corruption and Economic Crime (DCEC) has reported an increase in the number and complexity of cases of corruption. The objective of this paper is to assess the role of the non-state actors (NSAs) in fighting corruption in Botswana. This assessment is made by way of providing a description and analysis of the underlying challenges and opportunities confronting NSAs, specifically the private (business) sector, the private media and nongovernmental organisations in preventing and addressing corruption in Botswana. NSAs play a pivotal role in the development of any country by providing goods and services, creating awareness and sensitizing communities on political and socio-economic issues affecting them. Whereas NSAs have a key role to play in fighting corruption by monitoring the use of public resources, educating the public, condemning perpetrators, and contributing towards the implementation of anti-corruption instruments, they are confronted by political, legislative and institutional challenges that hinder their effectiveness in this regard.
\end{abstract}

Keywords: Botswana, corruption, ethics, governance, non-state actors

\section{Introduction}

This paper provides an overview of the role of non-state actors in preventing and combatting corruption in Botswana. The country's lead anti-corruption agency, the Directorate on Corruption and Economic Crime (DCEC) has reported an increase in the number of cases of corruption in the public sector (DCEC, 2013). On the other hand, in his 2015 Budget Speech, the Minister of Finance and Development Planning, Kenneth Matambo, stressed the importance of improving public sector efficiency. Matambo reported losses incurred by government's project implementation partners, namely the Botswana Power Corporation (P1.3 billion) and Water Utilities Corporation (P191.1 million) during the 2013/14 financial year (Republic of Botswana, 2015). While it cannot conclusively be stated that such financial losses were as a result of corrupt or illicit activities, this picture illustrates the consequences of poor implementation which leads to losses in public finance - highlighting the need for strengthened oversight mechanisms during the implementation of projects.

Botswana has done consistently well in contributing towards the fight against corruption. Transparency International (TI) ranks Botswana as the least corrupt country on the African continent (Transparency International, 2015). In 1994, the government of Botswana established the Directorate on Corruption and Economic Crime (DCEC), and in 2013, the government in collaboration with the Commonwealth Secretariat established the Commonwealth Africa Anticorruption Centre (CAACC). Public awareness of corruption has also risen as evidenced by the fact that the DCEC has seen an increase in the number of reported cases from the general public (DCEC, 2013).

While Botswana is party to international and regional anti-corruption instruments such as the United Nations Convention against Corruption (enforced: 14 December 2005), African Union Convention on Preventing and Combating Corruption (enforced: 05 August 2006), and the SADC Protocol Against Corruption (enforced: 06 August 2003), some evidence suggests that gaps exist in the implementation of these mechanisms. For instance, each of the aforementioned conventions strongly advocate for, amongst others, the promotion of access to information, protection of whistleblowers, and transparency in public procurement processes. However, Botswana is yet to establish and implement appropriate formal mechanisms that adequately address these gaps. 
Lack of access to state-held information remains an impediment to the capacity of the private media, civil society and other investigative bodies to fight corruption. Unlike some of its SADC counterparts, namely; South Africa, Zambia, Swaziland, Mozambique, and Malawi, Botswana is yet to adopt a formal anti-corruption strategy or policy. BIDPA (2014:10) affirms that the national anti-corruption legal framework is currently disintegrated and fragmented, reflective of what has been the lack of coherent policy approach to corruption.

\subsection{Rationale for the Study}

Three justifications provide the rationale for this study as follows:

1) The Directorate on Corruption and Economic Crime has reported an increase in the number of cases of corruption in the country. The DCEC's efforts to prevent and address incidents of corruption have been constrained by a number of institutional and legislative impediments. In light of current challenges, it is imperative to determine how collaborative efforts between the DCEC and non-state actors can be enhanced.

2) The role played by non-state actors in extending democracy and providing services make them significant actors in the democratic process as they extend the call for accountability on the executive and to a lesser extent, the legislative branches of the state. The need to identify challenges and opportunities confronting them to effectively contribute to anti-corruption efforts can assist in determining their effectiveness to prevent corruption.

3) Botswana is party to a number of international and regional anti-corruption conventions, which advocate for the state to encourage civil society participation, through the implementation of measures such as ensuring public access to information and undertaking public information activities that contribute to non-tolerance of corruption. Implementation shortcomings exist however, which bring about the need to identify and address bottlenecks to prevention of corruption.

\subsection{Organisation of the Paper}

The paper is organised as follows: the next section discusses the methodology and objectives of the study. Thereafter, the paper will provide a description of the key concepts that are used. A discussion detailing the background and current status of corruption in Botswana will follow before an analysis of the roles of non-state actors in anti-corruption is explored. The last section will conclude the paper by restating major discussion points and making policy recommendations.

\section{Research Methodology and Objectives}

A number of approaches were used in the collection of information necessary to carry out the study. These include the analysis of available international literature as well as local literature on governance and corruption. Face to face interviews as well as interview notes gathered during the drafting of the National Anti-Corruption Policy were the main methods of data collection. Specifically, interview notes accessed were those of respondents from Botswana Council of Non-Governmental Organisations, Business Botswana and the private media.

\subsection{Objectives of the Research}

The overarching research question is "What is the role played by non-state actors in preventing corruption?" The study was guided by the following objectives:

1) To establish the role played by non-state actors in preventing and combatting corruption in Botswana;

2) To highlight the challenges and opportunities confronting non-state actors in preventing and combatting corruption in Botswana; and

3) To provide recommendations aimed at strengthening anti-corruption efforts between the DCEC and NSAs.

\section{Conceptual Framework}

This section discusses the major concepts used in this paper and summarises pertinent literature relating to the role of NSAs in preventing and addressing corruption. This discussion assists in providing a context in which a structured analysis of the role of non-state actors in preventing and combatting corruption can take place.

\subsection{Corruption}

A review of literature (Transparency International, n.d.; Business Botswana, 2011; UNODC, 2001; SADCCNGO, n.d.; World Justice Project, 2015) suggests that there is no general agreement on the definition of corruption. According to Transparency International, corruption is the abuse of entrusted power for private gain (n.d., para. 1). It can be classified according to three categories; grand, petty and political, depending on the amounts of money lost and the sector where it occurs. The United Nations Office on Drugs and Crime defines corruption as 
a crime committed by officials (public or private) abusing of their role to procure gain for themselves or somebody else. Several forms of corruption exist: bribery, embezzlement, abuse of power, money laundering, etc. (UNODC, 2001.). The World Justice Project (2015: 35) asserts that corruption can take many forms - including bribery, nepotism, extortion, embezzlement, fraud, and involvement with organized crime - and may involve a variety of public servants.

SADCCNGO (n.d.: 34) on the other hand refer to corruption as the result of morally degenerate or weak individuals who overlook their role as public servants to serve their own interests. On the other hand, Business Botswana (2011:7) defines corruption as the "misuse of public powers, office and authority for private gain through bribery, extortion, influence peddling, nepotism, fraud, speed money or embezzlement". According to BIDPA (2014: 4) corruption has many effects on any society, which if not prevented or mitigated can have far reaching negative consequences for the wellbeing of nations, families, communities and businesses. According to SADCCNGO (n.d.) World Bank Governance Indicators, which address corruption under the indicator 'control of corruption', have consistently ranked Botswana in the highest percentile of African countries surveyed.

\subsection{Non-State Actors}

Along with government and business, non-state actors are an integral sector of society. According to the European Union (2000), NSA's are a broad range of non-governmental development actors, encompassing the private (for profit) sector, economic and social partners (including political parties and trade union organisations) and civil society in all of its forms. Contrasting theories (Calame, 2008; Clapham, 2009; Halliday, 2001; Josselin and William, 2001) aimed at defining non-state actors offer varying perspectives on this discussion. Some texts examine the notion of NSAs from a legal perspective; acknowledging that entities that are not part of the state are non-state in nature. Other arguments have been made regarding the relevance of studying non-state actors because of their power and influence on the policy process. Notwithstanding the different views of the concept, it is generally agreed that the role of non-state actors is to facilitate public participation. Common characteristics and functions exist amongst non-state actors, but the most prominent role that they play is to limit and control the power of the state. Ghaus-Pasha (2004:3) identifies the following additional features of NSAs: separation from the state; formed by people who have common needs, interests and values; and development through a fundamentally endogenous and autonomous process which cannot easily be controlled from outside.

According to UNECA (2008:122) and Phirinyane (2013:99) the government of Botswana has established clear systems for consultation with non-state actors to enhance structured engagements. In addition, there is openness in the political system, and government consults the public on policy and legislation. However, there is a perception that because Botswana's political culture is largely centralized (Molutsi, 1998; Maruatona, 2002; PAIR Institute, 2002), most of this consultation adopts a 'top-down' approach; government merely informs its stakeholders, NSAs included, of its policies and plans rather than seeking inputs into the formulation of those policies and plans, a view strongly held by labour unions (Piet, 2013).

This paper focuses on three particular types of NSAs, namely; the private media, NGOs, and private sector. Each of these groups of NSAs play a unique role and their levels of interaction and influence on the policy process are somewhat varied.

\section{Background: Current State of Corruption in Botswana}

Botswana has been hailed as a shining example of a democracy on the African continent (Samatar, 1999; Carbone, 2005; Cook and Sarkin, 2010). Spurred on by high levels of economic growth, social and political stability, Botswana's rise from being one of the poorest countries in the world to an upper middle income country is well documented (World Bank, 2008). However, emerging policy challenges based on a number of imperatives, such as the need to build organizational capacity for anti-corruption work, identify new forms of cooperation among state and non-state actors, and establish a framework against which corruption legislation and other interventions may be reviewed from time to time have highlighted the evolving nature of corruption and the importance of the state in providing an effective response.

International governance indices suggest that, comparatively, corruption in Botswana has not been as perverse as it has in other African countries (see Table 1). Yet perhaps Botswana has not always had such a clean record for managing corruption as corruption scandals in the 1990s resulted in the government of Botswana taking the issue of "ethics and corruption as very important to the long-term strategic objective of the nation" (Gbadamosi, 2006:12). It is also important to note that Botswana's colonial heritage had a bearing in shaping the political, economical and social landscape of the country, moreover, the relations between the state and indigenous groups. Whereas many other African countries were marred by political and ethnic conflict, and largely ruled by paternalistic, rent-seeking governments; this was not the case in Botswana. In contrast, Botswana's post-colonial 
up-bringing was characterized by shared values premised on nation building between the state and indigenous groups (Maundeni, 2002).

Table 1. Corruption perception index of selected African countries (2012 - 2015)

\begin{tabular}{lcccc}
\hline Country & $\mathbf{2 0 1 5}$ (World Rank) & $\mathbf{2 0 1 4}$ (World Rank) & $\mathbf{2 0 1 3}$ (World Rank) & $\mathbf{2 0 1 2}$ (World Rank) \\
\hline Botswana & 28 & 31 & 30 & 30 \\
Angola & 163 & 161 & 153 & 157 \\
Democratic & 147 & 154 & 154 & 144 \\
Republic of Congo & & & & \\
Nigeria & 136 & 136 & 144 & 139 \\
\hline
\end{tabular}

Source: Transparency International

\subsection{The Directorate on Corruption and Economic Crime}

The establishment of the DCEC in 1994 was an important step in the fight against corruption, particularly in reaction to the scandals that questioned the credibility and legitimacy of the government. According to its founding statute, the Corruption and Economic Crimes Act, or CECA, the DCEC was established with the mandate to; investigate, prevent, and educate the public on corruption issues. Since establishment, the organization has been confronted by a number of significant challenges, such as case overloads, limited budgets, legislative inadequacies, and the geographical spread of investigative areas DCEC officers are required to cover, which essentially hinder its capacity to investigate cases in a timely manner (DCEC; 2012, 2013, 2014). Other concerns pertain to the DCEC's independence, or lack thereof, primarily due to the fact that the DCEC does not report or account to the national legislature, but rather, the Office of the President.

Added to this is the thinking that since the Director General of the DCEC is both appointed by, and can only be removed from office by the President, his or her autonomy is limited. This has raised further questions about the independence of the DCEC and its ability to withstand political influence, particularly during its investigations of so-called important people or "big fish" whether in politics, business or other sectors of the state.

The foregoing notwithstanding, several factors are thought to be attributable to lack of robustness of the DCEC in the fight against corruption. These factors include the absence of legislation such as the Right to Information Act (RTI), Whistle Blower Protection and Declaration of Assets and Liabilities Act (BIDPA, 2014). A study by Afrobarometer (2015a) revealed that there is relatively strong support by Batswana (75\%) "agreeing/ strongly agreeing" that ministers, MPs, and other government officials be required to publicly declare their assets and liabilities (see Figure 1).

Closely related to the requirement of officers declaring their assets and liabilities, is the need for regular and robust lifestyle audits of politicians and public servants to ensure that it is harder for the proceeds of crime and corruption to be concealed by those that hold public office (SADCCNGO, n.d.).

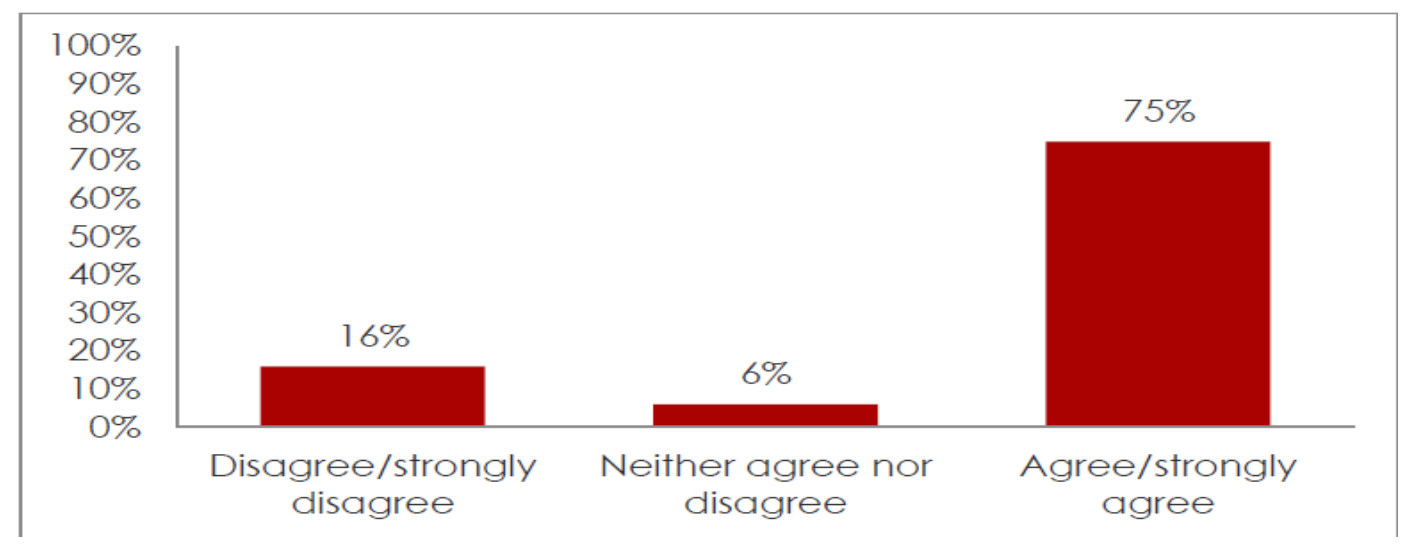

Figure 1. Declaration of assets and liabilities

Source: Afrobarometer (a, 2015) 
Civil society has a duty to keep elected officials accountable by demanding answers for decisions and actions that are taken or not taken on their behalf, but the absence of legislation that empowers citizens to directly or indirectly question government on issues such as failed tender bids, conflicts of interest, recruitment procedures and decisions, limits this interaction. However, this type of engagement is supported by institutions such as the Mo Ibrahim Foundation (n.d., para.2) and World Justice Project (2015:12), which urge governments to be open by providing political, social and economic goods that empower citizens to demand accountability and participate in public policy deliberations.

Afrobarometer (2015a) indicates that Batswana perceive high and increasing levels of corruption amongst politicians and state institutions, which corroborates DCECs findings regarding public awareness of corruption. Moatlhaping and Moletsane (2012:30) are of the view that most citizens' limit their participation in public affairs because of a lack of access to information, and a general lack of transparency on the part of public institutions in the development of processes, including political life.

\subsection{Anti-corruption Legislation in Botswana}

The fight against corruption has demanded an active response from the state, not only through the establishment of institutions and partnerships, but more importantly, the promulgation of a legal framework that empowers these institutions to effectively carry out their anti-corruption mandate. Botswana is a member of the Eastern and Southern African Anti-Money Laundering Group (ESAAMLG), which has the objective of providing a regional response for money laundering. In addition to the Corruption and Economic Crime Act of 1994, the following legislation was introduced to combat financial irregularities in Botswana;

- Proceeds of Serious Crime Act, 2008: An Act to deprive persons convicted of serious crimes of the benefits or rewards gained from such crimes, and to deal with the problems of money laundering.

- Banking (Anti-Money Laundering) Regulations, 2003: An Act established to outline the operational responsibilities of Banks in Botswana, particularly in reporting any suspicious transactions to both the Central Bank and the Financial Intelligence Agency.

- Financial Intelligence Act, 2009: The FIA Act provides a comprehensive legal framework to support anti-money laundering activities in Botswana and the region. Furthermore, the FIA establishes the Financial Intelligence Agency, which is responsible for requesting, receiving, analysing and disseminating information on financial disclosures relating to suspicious transactions.

Money laundering only seeks to undermine economic development. Therefore, as Botswana continues to strengthen its anti-corruption mechanisms, it is vital that anti-corruption agreements with its regional and international counterparts are established to ensure that Botswana does not become a money laundering haven for individuals and organizations with illicit intentions.

\section{The Role of NSAs in Preventing and Combatting Corruption}

This section describes the roles of non state actors in combatting corruption in Botswana.

\subsection{The Role of Non-Governmental Organisations in Anti-Corruption}

Traditionally, NGO involvement in mainstream anti-corruption work has been minimal. Limited resources and capacity constraints have curtailed the efforts of NGOs in achieving their operational and strategic objectives, let alone conducting anti-corruption work. Nonetheless, BOCONGO has in place a code of conduct (NGO Code of Conduct: a Standard for Moral, Social and Ethical Behaviour for Civil Society in Botswana, of 2000) which members have to abide by. The code of conduct represents commitments made by members of the NGO community to regulate their conduct. Currently, Botswana does not have an NGO that specializes in anti-corruption work so there is a dependency on the national anti-corruption agency to disseminate information and actively forge partnerships with various communities and representative bodies.

\subsubsection{Challenges Confronting NGOs}

One of the pertinent challenges facing NGOs relates to a lack of funding, which makes these organisations desperate and ultimately vulnerable to the influence of benefactors. Furthermore, a lack of funding results in NGOs' inability to effectively compete for business with other service providers. Legally, the scope of the DCEC Act does not include NGOs because the emphasis is currently limited to curbing corruption in the public sector. An apparent limitation of the code of conduct is the voluntary provisions it makes with regards to monitoring and evaluation. Section 5 (2) of the code of conduct stipulates that members shall "voluntarily monitor and evaluate their own performance". The absence of a corruption prevention strategy makes the voluntary code of conduct the solitary guiding document for encouraging ethical behavior. BOCONGO is also of the view that 
"there is a lack of transparency and information sharing in the public sector" (BOCONGO, 2015).Not only does this limit NGO participation in public spaces; it also results in low levels of public trust in the regime level because of the influence NGOs have in communities. BIDPA (2014) states that current mechanisms (e.g. kgotla meetings) for addressing corruption are not user-friendly to the youth, as they do not have time to attend nor feel welcome in these forums. Other identified challenges with regards to mainstream anti-corruption work relate to the limited capacity of NGOs to review and contribute to the UNCAC National Implementation Reports (BOCONGO, 2015).

\subsubsection{Opportunities for NGOs in Anti-Corruption}

The participation of NGOs is deemed important for representing and protecting stakeholder rights and interests, promoting their welfare and forging a sense of ownership of policies and programmes. It has been argued that NGOs in Botswana have capacity constraints in advocacy and engagement with the state. However, Kaboyakgosi (2013:29) suggests that despite their limitations, these organisations have challenged the government on key issues of public concern.

Internally, BOCONGO has a system of checks and balances, particularly in relation to financial procedures. Authorizations and approvals are not conducted by the same individual, the finance office plays a compliance role and the overall procurement process is believed to be efficient. Comparatively, Botswana lags behind her SADC counterparts in promoting NGO participation in curbing corruption. The SADCCNGO (n.d.) cites countries such as Mozambique, Zambia and South Africa as having in place mechanisms that promote NGO participation. Vital to this process, is the existence of a legal and political environment that shapes the extent and impact of civil society involvement in combating corruption. NGOs can play a crucial role in supporting the government to meet its UNCAC obligations and acting as an independent observer of the government's implementation of the UNCAC.

It is difficult to argue against the fact that while NGOs in Botswana have an important role to play in anti-corruption initiatives (e.g. awareness creation and public education); the current operational environment provides a significant challenge for them to contribute effectively towards the implementation of anti-corruption measures. The DCEC must continue to engage civil society at the appropriate levels to ensure buy-in and support of ongoing initiatives. Once enforced, the DCEC or appropriate body tasked with the implementation of the Declaration of Assets and Liabilities Act can capacitate NGOs to monitor and provide feedback or oversight on the declaration scheme. In addition, the DCEC has been vital in providing training and development opportunities to NGOs in communities as a way of promoting participation in anti-corruption work.

Trade unions, churches, and faith-based organisations (FBOs) are positioned to support or denounce illicit government and private conduct. Their impartiality is imperative and, thus, should not be perceived to represent factionalist interests, but democracy. NGOs can play a key role in the reintegration into society of persons convicted of corruption.

\subsection{The Role of Private Media in Anti-Corruption}

The media (print and radio) in Botswana has proven itself to be an alternative voice to issues of public interest and interpretation. According to Balule (2013:13) the media serves two important public interests in a democratic society; firstly, to facilitate the free flow of information, and secondly, to play a watchdog role. In other words, the media's role is to provide information on governments, that is; 'what they are expected to do, and how, when and why' (UNECA, 2009).

Ndlovu (2012:77) states that the media in Botswana is relatively vibrant and has shown its tenacity in pursuit of corruption stories. Over the years, media freedom has become a key indicator in assessing good governance. Afrobarometer (2015b) suggests that in order to provide the public with accurate information about public affairs, the media must be free to report without government interference.

The UNECA (2008) argues that although Botswana's press is free, it is rather small, and its ownership is concentrated. Its effectiveness as a watchdog is doubtful because it lacks influence in the political system. Balule (2013) expands on this view by arguing that the broadcast sector has not grown satisfactorily since the liberalization of the airwaves.

The sector is still, according to Balule, dominated by state-owned broadcasters. A study by Afrobarometer (2015b) revealed that $23 \%$ of the respondents were of the view that the media "Often/ always" abuses its reporting privileges by publishing 'things it knows are not true'. Nevertheless, the majority of respondents (65\%) indicated that the media "Never/ rarely" abuses its freedom. In comparison, Botswana ranks relatively better in this regard than its regional counterparts (see Figure 2). 


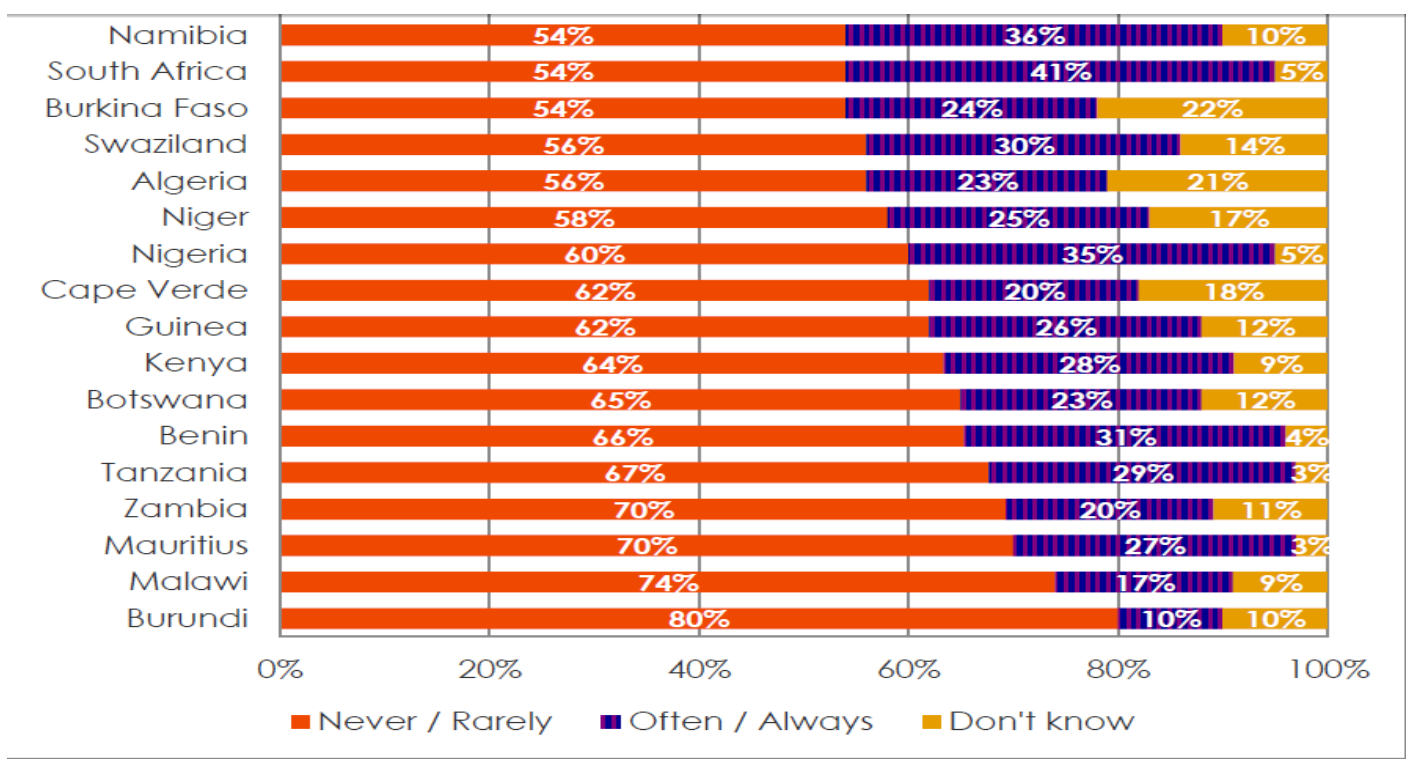

Figure 2. Frequency of abuse of media freedom

Source: Afrobarometer (b, 2015)

Stapenhurst (2000: 15) argues that the media are empowered to lead the fight against corruption, underdevelopment, and human rights, but at the same time, it must ensure its own accountability. Arguments on whether or not the state should regulate the media or allow the media to become self-regulating have been contentious in most democratic states (Djankov, et.al., 2003 and Fielden, 2012). While the media has operated, largely free from government interference, Van Klaveren, et.al (2009) cite 'disquieting developments' that describe government's relationship with the media as antagonistic. The scholars argue that in 2008, GoB occasionally censored stories it deemed undesirable and, ultimately, the Media Practitioners Act was legislated.

A delicate balance exists between the government's role in protecting state classified information on the one hand, while ensuring the protection of the media's constitutional right to freedom of expression on the other. The Press Council of Botswana (PCB) was established in 2002 as a voluntary self-regulating body. Its principal objective is to promote and protect the development of a free, ethical, pluralistic news media. However, according to Balule (2013: 20) the PCB has not been successful in effectively regulating the media due to a number of challenges, such as the organization lacking effective enforcement mechanisms (no penal sanctions against violating members), and due to its voluntary nature, it essentially means that it depends on members to abide by its decisions. The PCB's inability to effectively sanction members that publish unsolicited or defamatory stories about individuals or entities will only raise doubts about its credibility and influence in the fight against corruption.

\subsubsection{Challenges Confronting Private Media}

A number of challenges affect the work of private media in carrying out anti-corruption work. The introduction of the Media Practitioners Act in 2008 was met with immediate resistance by members of the media fraternity, as they perceived the legislation to be an attempt, on the part of government, to muzzle the media's right to 'freedom of expression'. The Media Institute of Southern Africa (MISA, 2009: 4) described the introduction of the legislation as a "major setback not only for media freedom and freedom of expression, but to the general democratic character of that society." Furthermore, Botlhale (2012:60) argues that the absence of legislation promoting access to information, and given the existence of instruments such as the Media Practitioners Act (2008), the Intelligence and Security Act (2007) and the National Security Act (1986), there appears to be transparency challenges.

There is a perception, particularly amongst the media fraternity, that the current legislative framework is designed to stifle media freedom and effectively place the autonomy of private media under the control of the state. Recently, tensions have risen between the DCEC and local private media, on the basis that media houses are alleged to have contravened Section 44 of the Corruption and Economic Crime Act, which prohibits the disclosure of information on an ongoing investigation. An illustration of this occurred when the Botswana Gazette, a privately owned newspaper published an article of an ongoing investigation in early 2015, which 
subsequently resulted in the arrest of three journalists.

Another challenge facing the private media is its dependence on advertising revenue, which is largely derived from the state. Government has been accused of using its control of public funds to surreptitiously control the media. As an example, after two private newspapers, being The Botswana Guardian and MidWeek Sun, were issued with an advertising ban in early 2001, they approached the courts. On 24 September 2001, the High Court declared the ban unconstitutional reasoning that it violated the newspapers' constitutional rights to freedom of expression (IFEX, 2009).Similarly in late December 2014, the government reportedly issued a secret directive to its various ministries and parastatals to stop advertising in some private newspapers, among them The Sunday Standard, Mmegi, The Botswana Guardian, Weekend Post and The Patriot on Sunday (Ontebetse, 2014). Although there have been denials, these are worrying developments that have the potential to bias editorial policy, content and reportage in a certain direction.

According to a media respondent, "it is easier in Botswana for certain stories to be suppressed if they are negative to major advertisers" (Interview notes with Editor of Mmegi, 2014). The freedom to openly criticize poor government performance is a fundamental cornerstone of any democracy and should not result in the censorship of media houses that objectively report on issues of corruption. Other key challenges include; an inability to retain skilled personnel, particularly those that have established trust with key external contacts. Secondly, carrying out investigative journalism is an expensive undertaking that media houses can't always prioritize. Thirdly, the confluence of commercial and political elite media ownership makes it relatively difficult for journalists to freely publish stories involving these individuals, which essentially hinders objective content reporting (Ibid.). Balule (2013:19) also argues that the laws regulating the print media do not address competition aspects of the sector, which has given rise to the emergence of monopolies in the sector.

\subsubsection{Opportunities for Private Media}

Arguably, for its anti-corruption role to be effective, the media needs the presence of laws that support transparency, as well as the confidence, cooperation and trust of all other institutions. Phillpott (2012) identifies the following fundamental objectives of a right to information act;

- To make government more transparent and accountable;

- To improve decision making and enable the public to better understand decision making processes; and

- To engage public participation in politics and endear public trust on the workings of government.

The right to information law is primarily designed to remove the veil of secrecy that commonly characterizes governments in developing countries. The limits of secrecy should be defined by such a law and in a manner consistent with the publics" "right to know". Therefore, it is imperative for a conducive environment to be created for the media to continue playing a part as a watchdog of government's actions and policies. The enactment of the Right to Information Act is critical for the promotion and maintenance of good governance. Access to information is regarded as a human right and not only should Botswana adopt such a piece of legislation, it should also ensure that it upholds its provisions.

Despite the somewhat adverse relationship between the private media and the national anti-corruption body, potential for improving this relationship exists primarily because the DCEC (2014: 31) has been concerned that members of the public still find it difficult to understand what corruption is as evidenced by the number of reports received that do not fall within the mandate of the Directorate. Thus, it is essential that the DCEC engages private media houses to conduct, in addition to reporting on corruption, educational awareness on corruption. Arguably, the credibility of any anti-corruption initiatives largely depend on the extent to which they have the support and backing of the public.

The media plays a significant role in exposing cases of corruption by creating awareness and sensitizing the general public as well as authorities. There is an apparent need to reform the current legal environment to ensure that the media continues to play an effective watchdog role without fear or prejudice. The media needs to ensure that it disseminates factual information to the public and promote anti-corruption capacity building in the media fraternity. The media can only report freely and accurately to the public when there is little to no government interference.

\subsection{The Role of the Private Sector in Anti-Corruption}

Business Botswana (formerly Botswana Confederation of Commerce Industry and Manpower) was formed in 1971 and has been at the forefront of the private sectors' interests in Botswana. Business Botswana in collaboration with the DCEC developed the Code of Conduct for the private sector as part of the country's 
anti-corruption drive. The promulgation of the code of conduct in 2011 illustrated both the public and private sectors' commitment to fighting corruption in all sections of society. BIDPA (2014:11) also notes that the Competition Policy, adopted in 2005, advocates for the outlawing of corrupt practices such as bid rigging, collusion and other conduct in the market that may compromise competition.

According to the DCEC (2013) one of the biggest areas of corruption concern relates to the "cartels operating to cheat especially on the procurement of goods and services". Furthermore, the fact that Botswana does not have anti-corruption bilateral agreements with most countries significantly impedes one of the possible mechanisms of recovering property or money gained illicitly. Articles 54 and 55 of the UNCAC make provisions for member states to put in place measures aimed at recovering and or confiscating proceeds of crime, property or equipment. Moreover, there is a need to harmonize the penalties imposed by the Corruption and Economic Crime Act (under Section 36) as well as the Proceeds of Serious Crime Act (under Section 15 and 16). Whereas the CECA imposes a ten year imprisonment term or a fine not exceeding P500 000 on persons guilty of corruption, or both; the POSCA imposes, in the case of an individual; imprisonment for a term not exceeding three years or a fine not exceeding P10 000, or both, or if the offender is a 'body of persons, then, every person who at the time of the commission of the offence was a director, manager or partner of such body shall be liable to a fine not exceeding P25 000'.

\subsubsection{Challenges Confronting the Private Sector}

Arguably, increased opportunities for corrupt practices emerge in the private sector as compared to any other sector of the economy. The interface between the operations of government and business can result in the development of an environment that brews politically driven patronage. Man-wai (n.d.) is of the view that private sector corruption can cause much more damage to society than public sector corruption, for instance; corruption in financial institutions can result in market instability, equally, corruption in the construction sector can result in the establishment of dangerous structures. Therefore, equal emphasis should be placed on both sectors in order to eliminate double standards. The demand for transparency and accountability in the private sector has been expressed by organs of civil society, often citing the need for transparency in the financing of political parties and politicians by businesses. In line with this argument, the Business Botswana Code of Conduct for the Private Sector explicitly forbids members of the private sector from being subjected to political interference. Such a situation can result in the exchange of favours between politicians and businesses, in what has been termed "tenderpreneuring", which in turn compromises the integrity of government's procurement processes and investor confidence in businesses.

Unlike organs of the state, privately owned businesses do not account to the general populace, taxpayers or the electorate for the decisions or actions they undertake. Rather, accountability occurs internally; to the board or shareholders of the entity in question. However, the code of conduct stipulates that private sector members have a responsibility towards the communities in which they operate, through corporate social responsibility (CSR) initiatives. Although comprehensive and unequivocal on issues of ethical conduct in the private sector, the code of conduct is not legally binding for all members of the private sector. Implementation of the code of conduct has not been effective largely due to the fact that a majority of Business Botswana's members have not acceded to the voluntary article. Another challenge identified by BIDPA (2014:23) relates to the perception that Business Botswana has grown too close to government, which consequently, compromises it from speaking openly against corruption. Stemming from this concern is the fact that there are no prohibitions (e.g. insider trading legislation) for politicians and public servants that own businesses to trade or provide services to or on behalf of the state. This condition results in a conflict of interest because the relationship between the state and private sector becomes blurred.

The Competition Authority, as the regulator of business competition in Botswana, has noted a number of challenges with respect to carrying out investigations of possible cases of anti-competition and corruption. One such key challenge is government ministries' and departments' reluctance to share information for the purposes of investigating possible cases of anti-competitive practices (Competition Authority, 2014). The reluctance of government entities to share information with a statutory body like the CA can undoubtedly undermine any efforts to curb corruption, particularly as the Competition Authority has reported an increase in the number of cases of anti-competitive conduct since its establishment in 2009. For instance, the Competition Authority indicates that the Botswana Unified Revenue Service Act prohibits the Revenue Service from revealing tax information that could potentially assist the Authority implement counter corruption measures.

\subsubsection{Opportunities for the Private Sector}

Botswana's procurement laws (Public Procurement and Asset Disposal Act of 2001 and the Local Authorities 
Procurement and Asset Disposal Act) were formulated to regulate the procurement processes at central and local government. According to BIDPA (2014:15) a function of these Acts is to promote a competitive economy, whilst ensuring fairness and integrity amongst public contractors. Section 18.2.1 of the Code of Conduct for the Private Sector proposes that as a penalty for non-compliance, "the Procurement Act should be amended to stipulate that only firms that subscribe to and abide by the code of conduct shall be eligible to participate in tenders for the public procurement of goods and services at all levels of government." As government implements its privatization strategy, it is vital that private companies tasked with the responsibility of providing public functions or public services are also held accountable for actions and decisions taken. This is based on the premise that the public has a right to know how public funds are utilized.

It is apparent that corruption is a complex and yet sensitive topic. It affects economies, both developed and developing, in various ways. Government's decision to embark on a privatization exercise is necessitated by the need to diversify the economy, create opportunities for citizen entrepreneurship, improve efficiency in the delivery of public services, and reduce government administrative and financial burden (Republic of Botswana, 2000:9). While these policy objectives aim to reduce the burden on the state by increasing the role of the private sector in the economy, it is imperative that this exercise is carried out in a regulated and transparent manner.

With regards to whistle blower protection, section 14.4.5 of the code of conduct supports the concept and practice of whistle blowing, and further; protecting those that report unlawful, corrupt or harmful conduct. Whistle blowing is regarded as an effective anti-corruption tool and as such, it has become an integral part of anti-corruption practices around the world. Banisar (2011) argues that countries around the world have encouraged whistle blowing by establishing legal frameworks in both the private and public sectors that protect those that report unlawful conduct. In South Africa, the Protected Disclosures Act of 2000 was introduced as a measure to protect employees that report illegal conduct within their organisations. Likewise, India promulgated the Whistle Blowers Protection Act of 2011, to protect those that report any wrongdoing in government bodies, projects and offices. However, Botswana has not implemented such legislation.

According to Business Botswana (n.d.), its members are assisted to lodge or report complaints of corruption. The organization, in partnership with the DCEC promotes awareness campaigns about the consequences of corruption and has advocated for the need for incentivizing members that abide to the provisions of the code of conduct. Business Botswana is also of the view that laws compelling procuring officers in private companies to disclose their interests be promulgated as a way of curbing corrupt practices in the private sector. A relatively strong relationship exists between the private sector and the DCEC by virtue of the initiatives that have been implemented in partnership by the two organisations.

Along with the Competition Authority, another institution that was established within the country's broader anti-corruption regime is the Financial Intelligence Agency (FIA). The FIA was conceptualized as a result of the enactment of the Financial Intelligence Act of 2009. It has a mandate to request, receive, analyze and disseminate information on financial disclosures on suspicious transactions to law enforcement agencies, supervisory authorities and comparable bodies. It is important for the DCEC to continue strengthening its relations with the private sector and ensure active involvement of this sector in anti-corruption work.

The Business Botswana Code of Conduct is an indispensable anti-corruption tool and more counter-measures should be developed taking into consideration the evolving and complex nature of corruption. Private companies are pivotal to anti-corruption initiatives - they are aware of the conditions or determinants that are necessary for corruption to flourish and as such they can identify ways in which to address illegitimate practices. According to Webb (2008:598) while it is the duty of the state to impose costs (e.g. taxes) and regulations on companies, bribes could serve the purpose of lowering these costs. Companies may be willing to pay to receive a favourable interpretation of regulations, or even to reduce the imposed costs of such regulations. There seems to be an apparent relationship between government regulation in economic affairs and incidents of corruption.

\section{Conclusion and Recommendations}

\subsection{Conclusion}

This paper has examined Botswana's approach to fighting corruption by providing an overview of the role of non-state actors in preventing and combatting corruption. The paper argues that non-state actors are instrumental in promoting political, social and economic development, advocating policy change, as well as sensitizing and creating awareness amongst the public on issues of corruption. Botswana is a party to regional and international conventions, which all advocate, amongst others, the active participation of non-state actors in mainstream anti-corruption work. 
However, the paper asserts that the current political, legal and regulatory environment hinders effective participation of non-state actors. Three types of NSAs were discussed and it was argued that various constraints impede effective anti-corruption work. In light of national development and privatization efforts, it is no surprise that a greater degree of regulation and transparency is required from the state. The absence of key legislation such as whistle blower protection, right to information and declaration of assets and liabilities creates an environment that is perceived to hinder rather than support the engagement of non-state actors.

\subsection{Recommendations}

The paper has identified and discussed a number of policy gaps and imperatives. Therefore, the following recommendations are made:

1) There is a need to promulgate and implement laws (e.g. Right to Information, Whistleblower Protection and Declaration of Assets and Liabilities) that ensure a political and administrative commitment towards strengthening and enhancing transparency and accountability systems in the public service.

2) In order to dispel the perception that the DCEC is not an autonomous statutory body, the Director of the DCEC should report to the National Assembly and not the Office of the President. The impartiality of the DCEC should be closely guarded because this is essential to its credibility and reputation.

3) There needs to be continued government commitment towards strengthening stakeholder relations with non-state actors. The aim of this is to eliminate the perceived veil of secrecy by creating a culture of trust and openness.

4) There should be a clear understanding of the roles and responsibilities of various actors in the anti-corruption drive. Anti-corruption efforts should not be carried out in isolation, secrecy or in a manner that encumbers the attainment of the end goal.

5) All private companies that intend to engage in public-private partnerships should be compelled to subscribe and abide by the private sector code of conduct. Any conflicts of interest should be openly declared. This process would be effectively supported by the presence of the Declaration of Assets and Liabilities Act.

\section{References}

Afrobarometer. (2015a). Amid perceived escalating corruption, Batswana demand officials account and declare assets. Afrobarometer Dispatch No. 19.

Afrobarometer. (2015b). African publics back rights, responsibilities of media watchdogs. Afrobarometer Dispatch No. 27.

Balule, T. (2013). Media Regulation in Botswana - Managing Contested Policy Spaces. In Kaboyakgosi, G., Sengwaketse, M., \& Balule, T. (Eds.), Industry Regulation in Botswana. Gaborone: Lightbooks.

Botlhale, E. K. (2012). Accountability and Democracy. In K. Alexander, \& G. Kaboyakgosi (Eds.), A Fine Balance; assessing the quality of governance in Botswana (pp. 53-64). Pretoria: IDASA.

Botswana Confederation of Commerce Industry and Manpower. (n.d.). A Code of Conduct for the Private Sector. Retrieved July 18, 2015, from www.BOCCIM.co.bw

Botswana Council of Non-Governmental Organisations. (2015). Presentation on the Role of Civil Society in Fighting Corruption. Commonwealth Anti-Corruption Centre Conference. Gaborone International Conference Centre.

Botswana Institute for Development Policy Analysis. (2014). Situation Analysis for the Design of the National Anti-Corruption Policy of Botswana.

Calame, P. (2008). Non-state Actors and World Governance. Forum for a New World Governance Discussion Paper.

Carbone, M. (2005). Weak civil society in a hard state: Lessons from Africa. Journal of Civil Society, 1(2). http://dx.doi.org/10.1080/17448680500337574

Clapham, A. (2009). Non-state Actors. In A. Lexicon, \& C. Vincent (Ed.), Post-Conflict Peace building. New York: Oxford University Press.

Competition Authority. (2014). Annual Report 2013 - 2014. Retrieved August 7, 2015, from www.competitionauthority.co.bw/annual-report-201314

Cook, A., \& Sarkin, J. (2010). Is Botswana the Miracle of Africa? Democracy, the Rule of Law, and Human Rights Versus Economic Development. Transnational Law and Contemporary Problems, 19. 
Directorate on Corruption and Economic Crime. (2012). Annual Report 2012. Gaborone: Government Printer.

Directorate on Corruption and Economic Crime. (2013). Annual Report 2013. Gaborone: Government Printer.

Directorate on Corruption and Economic Crime. (2014). Annual Report 2014. Gaborone: Government Printer.

Djankov, S., Mcliesh, C., Nenova, T., \& Shleifer, A. (2003). Who owns the media? Journal of Law and Economics, 46. http://dx.doi.org/10.1086/377116

European Union. (2000). The Cotonou Agreement. Retrieved October 15, 2015, from http://www.europarl.europa.eu/document/activities/cont/201306/20130605ATT67340/20130605ATT67340 EN.pdf

Fielden, L. (2012). Press Regulation: Taking account of media convergence. The Foundation for Justice, Law and Society. Retrieved A 25, 2016, from http://www.fljs.org/sites/www.fljs.org/files/publications/Fielden.pdf

Gbadamosi, G. (2006). Corruption Perception and Sustainable Development: Sharing Botswana's Anti-Graft Agency Experiences. South African Journal of Economic and Management Studies.

Ghaus-Pasha, A. (2004). Role of Civil Societies in Governance. $6^{\text {th }}$ Global Forum on Reinventing Government Towards Participatory and Transparent Governance. Seoul, Republic of Korea.

Halliday, F. (2001). The Romance of Non-state Actors. In Daphné, J., \& William, W. (Eds.), Non-state Actors in World Politics. New York: Palgrave. http://dx.doi.org/10.1057/9781403900906_2

Howlett, M., \& Ramesh, M. (2003). Studying Public Policy: Policy Cycles and Policy Subsystems. Ontario: Oxford University Press.

IFEX. (2009). High Court declares advertising ban against newspapers unconstitutional. Retrieved April 7 , 2016, from https://www.ifex.org/botswana/2001/09/28/high_court_declares_advertising

Interview Notes. (2014). Interview with Editor of Mmegi Newspaper.

Josselin, D., \& William, W. (2001). Non-state Actors in World Politics: A Framework. In Daphné J., \& William W. (Eds.), Non-state Actors in World Politics. New York: Palgrave. http://dx.doi.org/10.1057/9781403900906

Kaboyakgosi, G. (2013). State, Society Structure and Process of Governance. In Phirinyane, M. B. (Ed.), Elections and the Management of Diversity in Botswana. Gaborone: Lentswe La Lesedi.

Mai-wai, T. K. (n.d.). National Anti-Corruption Strategy: The Role of Government Ministries. Retrieved July 19, 2015, from http://www.unafei.or.jp/english/pdf/RS_No79/No79_18VE_Man-wai1.pdf

Maruatona, T. L. (2002). A Critique of Centralized Curricula in Literacy Programs: The Case of Botswana. Journal of Adolescent \& Adult Literacy, 45(8).

Maundeni, Z. (2002). State Culture and Development in Botswana and Zimbabwe. The Journal of Modern African Studies, 40(1). http://dx.doi.org/10.1017/S0022278X01003834

McNeil, M., \& Malena, C. (2010). Demanding Good Governance. Washington D.C: World Bank. http://dx.doi.org/10.1596/978-0-8213-8380-3

Media Institute of Southern Africa. (2009). Annual Report 2009. Retrieved July 21, 2015, from http://www.misa.org/downloads/MISA\%20AR\%202009.pdf

Moatlhaping, S. O., \& Moletsane, K. (2012). Participation and Democracy. In Alexander, K., \& Kaboyakgosi, G. (Eds.), A Fine Balance: Assessing the Quality of Governance in Botswana. Pretoria: Idasa.

Ndlovu, T. (2012). Political Freedoms and Democracy. In Alexander, K., \& Kaboyakgosi, G. (Eds.), A Fine Balance: Assessing the Quality of Governance in Botswana. Pretoria: Idasa.

Ontebetse, K. (2014). Govt bans advertising on critical media houses. (The Sunday Standard, 15 December 2014). Retrieved April 7, 2016, from http://www.sundaystandard.info/govt-bans-advertising-critical-media-houses

PAIR Institute. (2002). An overview of Intergovernmental Relations in Africa. Pretoria: SAFPUM Publishers.

Phillpott, M. (2012). Freedom of Information Act - Benefits and limitations of the Act. Retrieved October 15, 2015 , from https://ihrprojects.wordpress.com/2012/01/30/freedom-of-information-benefits-and-limitations-of-the-act/ 
Phirinyane, M. B. (2013). Elections and Managing Diversity. In Phirinyane, M. B. (Ed.), Elections and the Management of Diversity in Botswana. Gaborone: Lentswe La Lesedi.

Piet, B. (2013). ILO includes Botswana in axis of evil. Mmegi Newspaper. Retrieved October 15, 2015, from http://www.mmegi.bw/index.php?sid=1\&aid=906\&dir=2013/june/thursday 20

Republic of Botswana. (2000). Privatisation Policy of Botswana. Gaborone: Government Printing and Publishing Services.

Republic of Botswana. (2015). Budget Speech.Retrieved August 7, 2015, from http://www.gov.bw/

Samatar, A. I. (1999). An African Miracle: State and Class Leadership and Colonial Legacy in Botswana Development. Portsmouth: Heinemann.

Southern Africa Development Community Council of Non-Governmental Organisations. (N.d.). SADC Protocol Tracker Report on Corruption. Gaborone: SADC Council of NGOs.

Stapenhurst, R. (2000). The Media's Role in Curbing Corruption. World Bank Institute.

Transparency International. (n. d). What is Corruption? Retrieved July 7, 2015, from $\mathrm{http}: / /$ www.transparency.org/what-is-corruption/\#define

UNECA. (2008). The Progress of Good Governance in Botswana. Gaborone: Bay Publishing.

UNECA. (2009). African Governance Report II. New York: Oxford University Press.

UNODC. (2001). Draft United Nations Manual on Anti-Corruption Policy. Vienna: United Nations.

Van Klaveren, M., Tijdens, K., Hughie-Williams, M., \& Martin, N. R. (2009). An Overview of Women's Work and Employment in Botswana. Decisions for Life MDG3 Project Country Report No.3. Amsterdam Institute for Advanced Labour Studies.

Webb, W. (2008). A Caveat on Public Management Reform and Corruption Prevention. Journal of Public Administration, 43(4).

World Bank. (2008). The Growth Report: Strategies for Sustained Growth and Inclusive Development, Commission on Growth and Development. Washington D.C.: World Bank. http://dx.doi.org/10.1596/978-0-8213-7491-7

World Justice Project. (2015). Rule of Law Index Report. Retrieved August 7, 2015, from www.worldjusticeproject.org/rule-of-law-index

\section{Copyrights}

Copyright for this article is retained by the author(s), with first publication rights granted to the journal.

This is an open-access article distributed under the terms and conditions of the Creative Commons Attribution license (http://creativecommons.org/licenses/by/4.0/). 